\title{
Effect of Agronomical and Technological Treatments to Obtain Selenium-Fortified Table Olives
}

\author{
Alessandra De Bruno, Amalia Piscopo *, Francesco Cordopatri, Marco Poiana and Rocco Mafrica \\ AGRARIA Department, University Mediterranea of Reggio Calabria, Vito, 89124 Reggio Calabria, Italy; \\ alessandra.debruno@unirc.it (A.D.B.); cordopatrif@gmail.com (F.C.); mpoiana@unirc.it (M.P.); \\ rocco.mafrica@unirc.it (R.M.) \\ * Correspondence: amalia.piscopo@unirc.it; Tel.: +39-965-1694366
}

Received: 7 June 2020; Accepted: 6 July 2020; Published: 10 July 2020

\begin{abstract}
The biofortification of food crops for human consumption is a direct strategy for increasing dietary intake of selenium (Se). The aims of this study were the evaluation of different Se-fortification variables (concentration and number of foliar applications) for obtainment of fortified olives and the efficacy of two technological treatments (brining and dehydration) applied to them in the maintenance of this element. The research was carried out in two experiments: the results of first one were that the application of the highest Se concentration $\left(75 \mathrm{~mL} \mathrm{~L}^{-1}\right)$ on olive trees was useful to obtain fortified Gordal olives $\left(650 \mu \mathrm{g} \mathrm{kg}^{-1}\right)$ but the further brining process did not allow an acceptable retention of this nutrient in olive pulp for its dissolution in brines: the decrease was from 92 to $99 \%$. The second experiment concerned in different number of foliar applications of the best previously tested Se-solution $\left(75 \mathrm{~mL} \cdot \mathrm{L}^{-1}\right)$ to obtain fortified Carolea olives, that were then submitted to different drying processes to became edible. The available selenium in the final products was better retained in olives dried without any preliminary treatment prior to drying and in those pre-treated by dried salt, with different trends linked to foliar application number.
\end{abstract}

Keywords: antioxidant activity; brining; dehydration; olive cultivars; plant treatments; selenium fortification

\section{Introduction}

Biofortification is an agronomic practice that allows one to increase the absorption and accumulation of specific nutrients in plants [1]. Increasing the concentration of micronutrients (such as selenium) in plants aims to improve the nutritional quality of plant foods during plant growth and crop processing: selenium may modulate the fruit ripening process through its antioxidant and anti-senescence properties with beneficial effects in terms of post-harvest commercial life, and greater benefits for human health [2]. In recent years, human use of biofortified agricultural products has been proposed as a possible strategy to increase the intake of some micronutrients [3-7]. It has been estimated that micronutrient deficiencies affect almost half of the world's population $[6,8]$. One of the most frequent and dangerous deficiencies in human health regards selenium [9]: its deficiency is closely associated with hypothyroidism, cardiovascular disease, weakening of the immune system, male infertility, cognitive decline and the incidence of various tumours [10-13]. The Food and Nutrition Board of the U.S. Institute of Medicine has proposed a Recommended Dietary Allowance (RDA) of $55 \mu \mathrm{g} \mathrm{Se} \mathrm{day}{ }^{-1}$ for adults and a tolerable upper intake of $400 \mu \mathrm{g} \mathrm{Se} \mathrm{day}{ }^{-1}$ [14]. Plants have different abilities to accumulate and tolerate Se [15-18]. Most crop plants have a low tolerance to its high levels and contain less than $25 \mu \mathrm{g}$ of Se $\mathrm{g}^{-1} \mathrm{dw}$. However, they can tolerate and accumulate even high concentrations without growth reduction [19]. Selenium exists as inorganic and organic forms in nature [20]. Plant can take up it as selenate, selenite or organoselenium compounds, such as 
selenocysteine (SeCys) and selenomethionine (SeMet) [21-23]. Selenate is the most prevalent form of bioavailable Se and more water soluble than selenite [24,25]. The two forms of Se differ in terms of absorption and mobility within the plant [26]. Selenite uses phosphate transport as an assimilation pathway [26] while selenate moves through transporters and sulfate channels [27-29]. The use of the same uptake and transport mechanisms determines that the absorption of selenite is limited by high phosphate concentrations and that of selenate by high sulfur levels [29]. Selenite is rapidly converted into organic compounds in the roots, whereas selenate is delivered immediately to the xylem $[18,26,30]$ and translocated to leaves and metabolized in plastids via a sulfur assimilation pathway to SeCys or SeMet [31-33]. The selenium content in plants can be increased in several ways: by addition to the soil [34-36], using nutritive solutions containing selenium in hydroponic and aeroponic cultivation [37-39] and foliar application of solutions containing selenium [40-42]. Among these, the foliar application is more preferable than the application on the soil, as a result of more efficient absorption, minimum consumption of selenium salts and absence of residual effects [43-45]. Up to now, most of the studies on biofortification with selenium have been carried out on herbaceous crops, while those on fruit tree plants are very limited. However, the few studies conducted on this type of plant showed that selenium foliar applications during the vegetative-productive season can increase the selenium content in the fruits [42,46-49]. With regard to olive trees, some recent studies conducted on the "Maurino" and "Leccino" cultivars have shown that foliar treatments with sodium selenate are able to enrich the selenium content in the oil $[40,50,51]$. The Se foliar application has also increased the Se methionine, phenol, carotenoid and chlorophyll content, making it possible to obtain EVOO with a higher nutritional value and longer shelf life [51,52]. Until now, no studies have been conducted on the biofortification with selenium of table olives. Table olives, like olive oil, are an important component of the Mediterranean diet, highly appreciated by consumers both for their good flavour and for their nutritional properties. Their nutritional quality is high due to the presence of essential aminoacids for humans $[53,54]$. Olives are also good sources of essential fatty acids that have a positive effect on cholesterol metabolism [55] and play an important protective function against colon, breast and skin cancer [56]. Thanks to their antioxidant content (polyphenols, $\beta$-carotene, vitamin E) olives also play a protective role against damage caused by free radicals and are therefore a valuable aid in the prevention of aging and degeneration of tissues, as well as some tumour forms [57-59]. Table olives are also a good source of dietary fibre with a high level of digestibility [60,61]. The enrichment of selenium in table olives could, however, present some problems related essentially to the varietal aspects and to the transformation process. With regard to the first aspect, the quantity of selenium stored by the plants depends, in fact, not only on the availability of selenium but also on the ability of the plants to absorb and accumulate it [16]. Dugo and colleagues [62] showed that the olive tree cultivar can influence the selenium content in the oil. Regarding the second aspect, the olives before being eaten must be processed to remove their bitter flavour [63]. This transformation is carried out using different processing systems, such as Spanish-style, Californian-style and Greek-style techniques [64,65] and dehydration [66]. Many of the processing systems used to sweeten the olives cause an increase in the permeability of the cell membrane, thus implying the possibility that some biochemical compounds and mineral elements pass from the olive into the surrounding liquid [63]. This process can determine significant changes in the mineral composition between freshly harvested olives and processed ones [67]. Some mineral elements present in the olive before processing could be lost as a result of the transformation processes. This research aimed to evaluate the efficacy of different Se-fortification variables (concentration and number of foliar applications) from an agronomical point of view for a Se-fortified table olives production. Also the efficacy of two technological treatments (brining and dehydration) in selenium retention and overall olive quality was evaluated.

\section{Materials and Methods}

A schematic overview of whole experimental plan is presented in Figure 1. 


\subsection{Plant Treatment of the First Experiment}

The first experiment was carried out during the year 2016 in Lamezia Terme (15 m a.s.1., $16^{\circ} 16^{\prime} 58^{\prime \prime}$ E longitude, $38^{\circ} 53^{\prime} 11^{\prime \prime} \mathrm{N}$ latitude) on four-year-old olive trees of the Gordal cultivar, trained according to the open-center training system and spaced $6.0 \times 6.0 \mathrm{~m}$. The experimental site climatic conditions of 2016 and main soil characteristics of olive orchard are shown in Figure 2a and Table 1, respectively. Each olive tree (about $2.5 \mathrm{~m}$ tall and approximately $1.5 \mathrm{~m}$ diameter and $1.5 \mathrm{~m}$ height of canopy) was fertilized in mid-April with the controlled-release fertilizer DuraTec ${ }^{\circledR}$ Top 21 (Compo Expert, Monza e Brianza, Italy) using a dose of one kilogram/tree. From mid-April to mid-October trees were irrigated every day in early morning using drip lines (two drippers per tree, each with a flow rate of $12 \mathrm{~L} \cdot \mathrm{h}^{-1}$ ) and suppling water from $2 \mathrm{~h}$ /day to $3 \mathrm{~h}$ /day during the period of maximum consumption (from June to September).

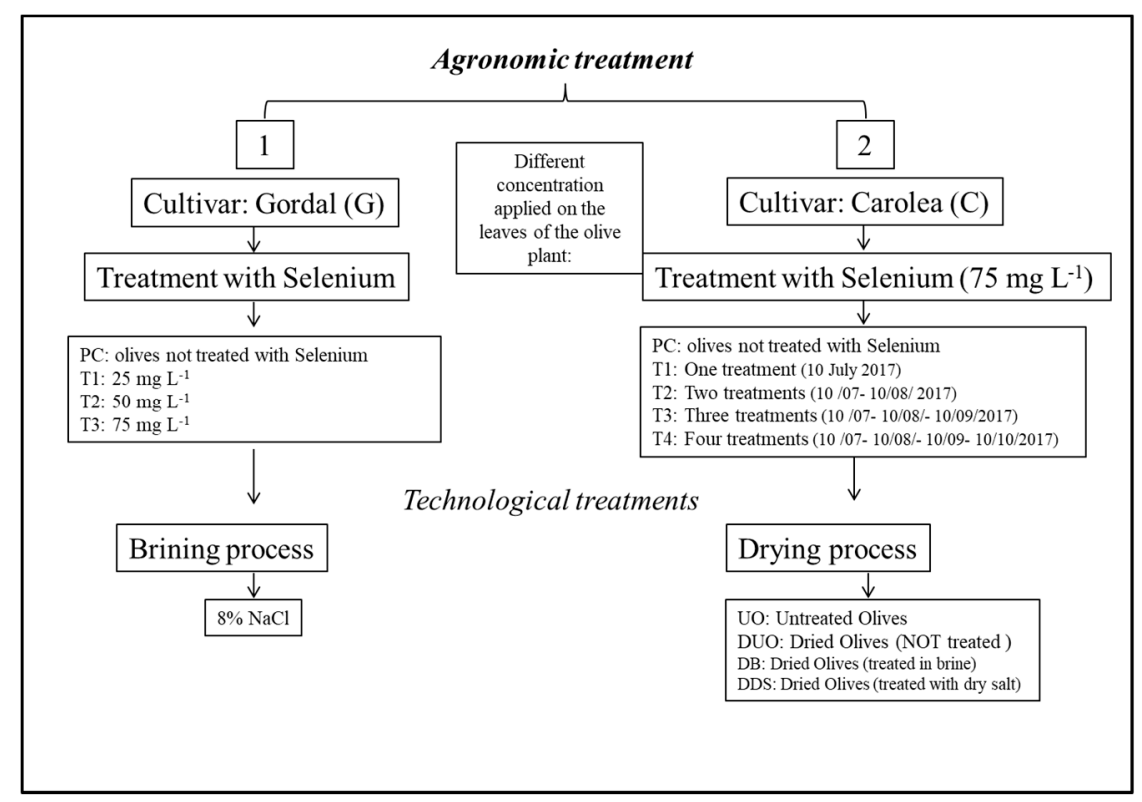

Figure 1. A schematic overview of the experimental plan.

In addition to the controlled-release fertilizer added to the soil, the plants were also fertilized by fertigation with nutrient solution, containing all plant macronutrients as reported in Table 2 three times weekly from April to October. During this period, each tree received in total $215.7 \mathrm{~g} \mathrm{~N}, 19.3 \mathrm{~g} \mathrm{P}$, $199 \mathrm{~g} \mathrm{~K}, 20.8 \mathrm{~g} \mathrm{Mg}, 244 \mathrm{~g} \mathrm{Ca}, 2.8 \mathrm{~g} \mathrm{Fe}, 1.5 \mathrm{~g} \mathrm{Mn}, 0.4 \mathrm{~g} \mathrm{Zn}$ and $0.2 \mathrm{~g} \mathrm{Cu}$. The olive orchard was under continuous monitoring for the main olive parasites, using pest control procedures that followed the principles of integrated pest management, when necessary. At 50,80 and 110 days after full bloom (DAFB), groups of 15 plants were sprayed with a solution containing three different Se concentrations: 25, 50 and $75 \mathrm{~mL} \mathrm{~L}^{-1}$ obtained by dissolving 50.8, 119.7 and $179.5 \mathrm{mg}$ of sodium selenate (S0882-25 g, Sigma-Aldrich, St. Louis, MO., USA) for each litre of water, respectively. For each treatment $0.5 \%$ of the wetting agent Bagnante antischiuma S (Sipcam Italia, Lodi, Italy) was added. Each tree was treated with a 1.6 L Se solution. In order to evaluate the quantity of effective solution left on the foliage, before the treatment an absorbent paper sheet was placed on the ground under the canopy of each plant. The sheet of paper was weighed before and after spraying to calculate the amount of solution retained by the foliage. On average this amount was about $80 \%$ of that sprayed. Considering the amount of total Se solution sprayed on the canopy and that actually retained by the foliage, during the entire experiment each plant received an amount of Se corresponding respectively to 96, 192, and $288 \mathrm{mg}$. The experiment also included a group of Plant control that was sprayed with a solution containing only water and the wetting agent. The foliar treatments were carried out during late afternoon, when wind speed was less than $7 \mathrm{~km} / \mathrm{h}$ and air temperature was less than $23^{\circ} \mathrm{C}$. Each treatment was composed of 
three blocks of five trees for each as replicates. The four plant treatments were arranged in the olive orchard according to a randomized complete block design. Between a block and the other a row of untreated plants was interposed to avoid interference on the selenate application, due to a possible "drift effect". Olives harvest was carried out on 2016 September 27 (142 DAFB).

\subsection{Plant Treatment of the Second Experiment}

The second experiment was carried out during the year 2017 in Feroleto Antico (197 m a.s.l., $16^{\circ} 21^{\prime} 54^{\prime \prime}$ E longitude, $38^{\circ} 57^{\prime} 14^{\prime \prime} \mathrm{N}$ latitude, using forty-year-old olive trees of the Carolea cultivar, trained according to the open-center training system and spaced $12.0 \times 12.0 \mathrm{~m}$. The trees were about $4.5 \mathrm{~m}$ tall and the canopy had a diameter of approximately $6.0 \mathrm{~m}$ and a height of about $3.5 \mathrm{~m}$. The experimental site climatic conditions of 2017 and main soil characteristics of olive orchard showed in the Figure $2 \mathrm{~b}$ and Table 1, respectively.

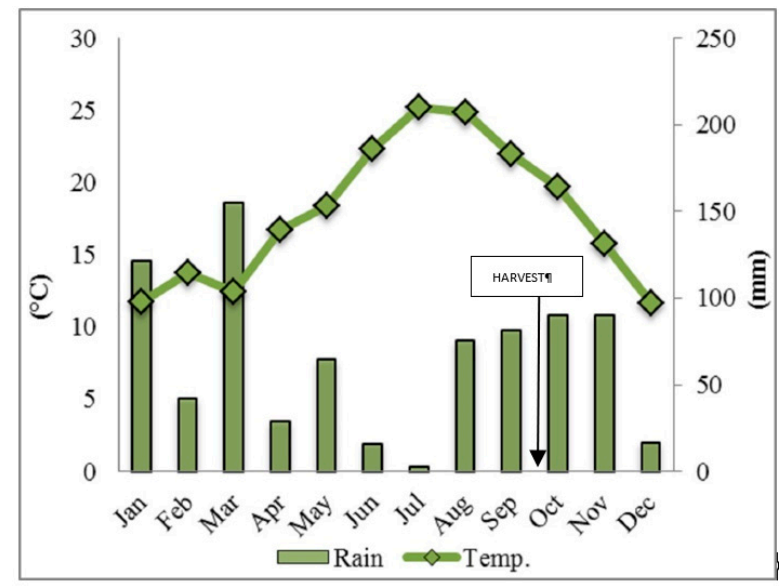

Expt 1

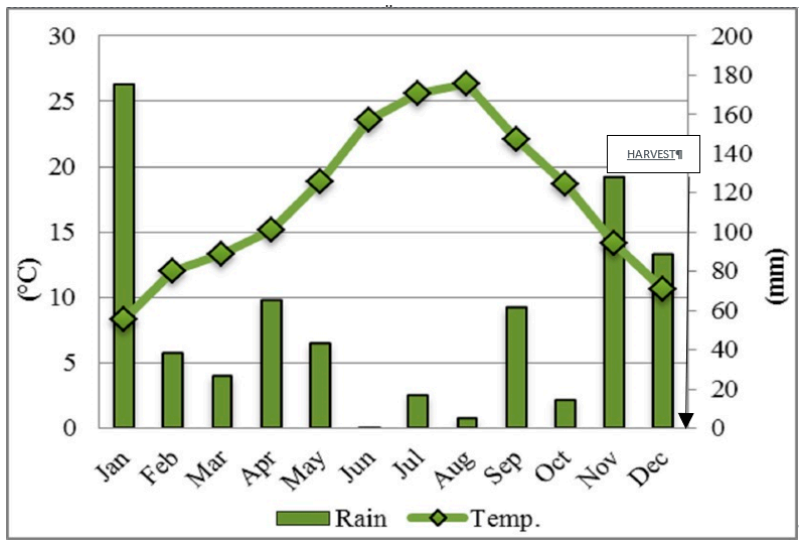

Expt 2

Figure 2. Mean monthly air temperature and monthly precipitation in the olive orchards where experiments were conducted in 2016 (Expt. 1) and in 2017 (Expt. 2). 
Table 1. Main physical and chemical characteristics of the olive orchard soils of first experiment at Lamezia Terme (LT) and the second experiment at Feroleto antico (FA).

\begin{tabular}{|c|c|c|}
\hline Parameter & LT & FA \\
\hline Sand $(\%)$ & 89.82 & 27.38 \\
\hline Silt (\%) & 3.64 & 20.93 \\
\hline Clay $(\%)$ & 6.54 & 51.69 \\
\hline $\mathrm{pH}\left[\mathrm{H}_{2} \mathrm{O}\right](1: 2.5)$ & 6.9 & 6.1 \\
\hline Total carbonates $\left(\% \mathrm{CaCO}_{3}\right)$ & 0.3 & 0.3 \\
\hline Active carbonates $\left(\% \mathrm{CaCO}_{3}\right)$ & 0.2 & 0.1 \\
\hline $\mathrm{EC}\left(\mathrm{mS} \mathrm{cm}^{-1}\right)$ & 0.3 & 0.2 \\
\hline Organic matter $(\%)$ & 0.1 & 1.6 \\
\hline $\mathrm{N}_{\text {tot }}(\%)$ & 0.1 & 1.2 \\
\hline $\mathrm{C} / \mathrm{N}$ ratio & 3.6 & 7.9 \\
\hline $\begin{array}{l}\text { Cation Exchange Capacity (meq } \\
\left.\qquad 100 \mathrm{~g}^{-1}\right)\end{array}$ & 28.5 & 42.8 \\
\hline $\mathrm{P}_{\mathrm{ava}}\left(\mathrm{mg} \mathrm{kg}^{-1}\right)$ & 7.7 & 8.8 \\
\hline $\mathrm{K}_{\mathrm{ex}}\left(\mathrm{mg} \mathrm{kg}^{-1}\right)$ & 43.0 & 167.8 \\
\hline $\mathrm{Ca}_{\mathrm{ex}}\left(\right.$ meq $\left.100 \mathrm{~g}^{-1}\right)$ & 16.4 & 34.3 \\
\hline $\operatorname{Mg}_{\text {ex }}\left(\right.$ meq $\left.100 \mathrm{~g}^{-1}\right)$ & 6.7 & 0.5 \\
\hline $\mathrm{Na}$ ex $\left(\right.$ meq $\left.100 \mathrm{~g}^{-1}\right)$ & 0.5 & 0.4 \\
\hline $\mathrm{Ca} / \mathrm{Ma}$ ratio & 2.5 & 69.7 \\
\hline $\mathrm{K} / \mathrm{Mg}$ ratio & 0.02 & 0.9 \\
\hline
\end{tabular}

Table 2. Nutrients concentration and fertilizers used for preparing the nutrient solution used for fertigation of olive orchard in Lamezia Terme used for the experiment in the year 2016.

\begin{tabular}{ccc}
\hline Element & Concentration $\left(\mathbf{m g ~ L}^{-\mathbf{1}}\right)$ & Source \\
\hline $\mathrm{N}$ & 150 & Ammonium nitrate and calcium nitrate \\
$\mathrm{P}$ & 13 & Orthophosphoric acid \\
$\mathrm{K}$ & 140 & Potassium sulphate \\
$\mathrm{Mg}$ & 14 & Magnesium sulphate \\
$\mathrm{Ca}$ & 170 & Calcium nitrate \\
$\mathrm{Fe}$ & 2.0 & Fe-EDTA \\
$\mathrm{Mn}$ & 1.0 & Mn-EDTA \\
$\mathrm{Zn}$ & 0.3 & Zn-EDTA \\
$\mathrm{Cu}$ & 0.1 & Cu-EDTA \\
\hline
\end{tabular}

Each olive tree was fertilized in mid-April with the controlled-release fertilizer DuraTec ${ }^{\circledR}$ Top 21 (Compo Expert) using a dose of one kilogram/tree. The fertilization to soil has been integrated with foliar applications ( $14 \mathrm{~L}^{-1}$.tree) of a $1.5 \%$ solution of specific water-soluble fertilizer Poly-Olive $15+7+30+2 \mathrm{MgO}$ with microelements (Poly-Feed ${ }^{\mathrm{TM}}$ Foliar-Haifa Italia, Bologna, Italy). Foliar treatments were repeated four times: before flowering, after fruit set, at pit hardening, and at the end of summer, before veraison. Foliar applications were performed during late afternoon, using an adhesive wetting agent Etravon Syngenta (Syngenta Crop Protection, Basel, Switzerland) at a rate of $0.05 \%(v / v)$. A different number of leaf sprays with a solution containing Se $\left(75 \mathrm{~mL} \mathrm{~L}^{-1}\right)$ were applied to the canopies of four groups of trees. The solution utilized to spray the foliage of the trees was obtained by dissolving the correct amount of sodium selenate (S0882-25 g, Sigma-Aldrich) in water. The foliar treatments with solution containing Se were carried out using the same precautions used in the previous experiment: spraying the plants during the late afternoon, in the absence of wind and adding to the $0.5 \%$ solution of the wetting agent Bagnante antischiuma S (Sipcam). The four groups of trees received a number of leaf applications that ranged from one to four: once at 50 days (T1), twice at 50 and 80 days (T2), thrice at 50, 80 and 110 days (T3) and four times at 50, 80, 110 and 140 days (T4) after full bloom. Each tree was treated with a $50 \mathrm{~L}$ Se solution. The amount of the sprayed solution actually retained by the canopy was evaluated with the same procedure described in Section 2.1. In this 
case the solution retention was about $70 \%$ of that sprayed. Considering the amount of total Se solution sprayed on the canopy and that actually retained by the foliage, during the entire experiment each plant was given an amount of Se corresponding respectively to 2.6 (T1), 5.3 (T2), 7.9 (T3) and 10.5 (T4) g. The experiment also included a group of untreated plant controls (PC). Each treatment was repeated on nine plants (three blocks of three plants each). The five treatments were arranged in the olive orchard according to a randomized complete block design. In order to avoid interference with different levels of humidity, at each time of treatment the plants not sprayed with the solution containing Se were sprayed with a solution containing water and wetting agent. Similarly, another experiment between one block and the other, a row of untreated plants was interposed to avoid interference. Olive harvest was carried out on 2018 January 26 (250 days after fool bloom-DAFB).

\subsection{Technological Treatments}

The technological treatments carried out on the two cultivars were different: natural fermentation for Gordal and drying for Carolea. Gordal olives were harvested at mature-green stage and immediately transported to the laboratory to be processed. They were calibrated and accurately washed to eliminate the Se traces in the drupe surface and, after, about $4.5 \mathrm{~kg}$ olives were subjected to lab-scale natural fermentation in $8 \% \mathrm{NaCl}$ solution in cylindrical glass fermenters. The olives were fermented at ambient temperature for 6 months and brines were periodically analysed to maintain the original salt concentration and a safe $\mathrm{pH}$ (4.3) by salinity and acidity corrections. Samples were named following the level of Se concentration sprayed in the leaves $\left(25,50\right.$ and $\left.75 \mathrm{ml} \cdot \mathrm{L}^{-1}\right)$ : low $(\mathrm{L})$, medium $(\mathrm{M})$, high $(\mathrm{H})$. The brining control olives were named BC.

Carolea olives were harvested fully ripe or slightly before full ripeness was reached, and immediately transported to the laboratory to be submitted to different drying processing. They involved the use of brine and dry salt as agents before the drying process.

About $3 \mathrm{~kg}$ of olives were put into $10 \mathrm{~L}$ plastic containers, filled with freshly prepared $25 \% \mathrm{NaCl}$ brine (heated to $40^{\circ} \mathrm{C}$ ) for $30 \mathrm{~min}$ (time required for the drupe to absorb the salt). Another sample of olives (about $3 \mathrm{~kg}$ ) was dipped for $2 \mathrm{~min}$ with water at $90^{\circ} \mathrm{C}$ and then preserved in alternating layers with dry salt for 6 days and named DDS. After the drying pre-treatments, the process of dehydration was performed by a tangential air-flow cabinet (Scirocco model, Società Italiana Essiccatoi, Milan, Italy), equipped with automatic temperature and air moisture control devices. Air flowed tangentially to fruits $\left(1840 \mathrm{~m}^{3} \mathrm{~h}^{-1}\right)$, while a recycling system allowed for mixing the exhaust with fresh air. The drying process was applied until the olives, placed on $56 \mathrm{~cm}$ diameter steel trays, reached a dry matter value near $90 \%$ (of final olive weight) estimated by weight loss calculation. Olive samples were named DB (olives pre-treated with brine and dried), DDS (olives pre-treated with dry salt), DUT (dried olives without any drying pre-treatment) and UT (fresh untreated olives).

\subsection{Analytical Methods}

At harvest a sample of 300 fruits for each treatment ( 100 fruits per block $\times 3$ blocks) were submitted to physical analyses. Fruit pigmentation was evaluated using the ripening index (RI), according to the method reported by Uceda and coworkers [68]. The flesh firmness was measured by PCE-FB 20 dynamometer with a tip of $1.5 \mathrm{~mm}$ of diameter. Dry matter (DM) was determined by oven drying at $105{ }^{\circ} \mathrm{C}$ up to constant weight. Official methods (UNI EN 13805:2014 + UNI EN 15763:2010) were followed for the determination of selenium content in fresh and treated olives.

Fresh and treated olives and corresponding brines were analysed for $\mathrm{pH}$ and total acidity (TA) [69]. Water activity (aw) was measured by an Aqua lab hygrometer (3TE, Decagon Devices Inc., Pullman, WA, USA). Total polyphenol content (TPC) was determined in sample extracts, according to literature [70] and with some modifications. Antioxidant capacity of samples was determined using the DPPH (2,2-diphenyl-1-picrylhydrazyl, Carlo Erba, Milan, Italy) and ABTS (2,2'-azinobis[3-ethylbenzo-thiazoline-6-sulfonic acid]-diammonium salt, Merck KGaA, Darmstadt, Germany) assays [71,72]. 


\subsection{Statistical Analysis}

All experimental results in this study were expressed as mean values of three measurements $(n=3)$. The significant differences $(p<0.05)$ among treatment means were determined by analysis of variance (ANOVA analysis) with Tukey's post-hoc test. SPSS Software (Version 15.0, SPSS Inc., Chicago, IL, USA) was used for data processing. Pearson's correlation coefficients ( $r$ ) were determined for relation between variables.

\section{Results}

Table 3 reports the physical characteristics of olive fruits cv. "Gordal" at harvest after the different plant selenate sprayings. No significant effect on the average drupe weight (6.5-6.6 g) and ripening index (close to 1, yellowish green skin colour) were observed on the fruits among the different Plant treatments. Significant differences were found regarding the flesh firmness: it was significantly higher in fruits of plants sprayed with $75 \mathrm{~mL} \mathrm{~L}^{-1}$ of selenate compared to the plant control and the other plant treatments. No difference between the plant treatments was found with respect to the flesh/stone ratio that had mean values around 5.3. The flesh moisture was not affected by the foliar applications of $\mathrm{Se}$, and flesh moisture values did not significantly differ among the plant treatments. The selenium content in olives at harvest varied from 180 to $641 \mu \mathrm{g} \mathrm{kg}^{-1}$ in accordance with the concentration of foliar applications. The selenium absorption and translocation through drupe appeared effective when the plant treatments concentration were higher than $25 \mathrm{mg} \mathrm{L}^{-1}$.

Table 3. Physical characteristics of olive fruits cv. "Gordal" at harvest after plant selenate spraying $(0$, 25,50 and $75 \mathrm{mg} \mathrm{L}^{-1}$ respectively for $\left.\mathrm{C}, \mathrm{L}, \mathrm{M}, \mathrm{H}\right)$.

\begin{tabular}{cccccc}
\hline Treatment & $\begin{array}{c}\text { Fruit Fresh } \\
\text { Weight } \mathbf{( g )}\end{array}$ & $\begin{array}{c}\text { Ripening } \\
\text { Index }\end{array}$ & $\begin{array}{c}\text { Flesh } \\
\text { Firmness } \mathbf{( k g )}\end{array}$ & $\begin{array}{c}\text { Flesh/Stone } \\
\text { Ratio }\end{array}$ & $\begin{array}{c}\text { Se Content } \\
\left(\boldsymbol{\mu g} \mathbf{~ k g}^{-\mathbf{1}}\right)\end{array}$ \\
\hline BC & 6.52 & 0.97 & $0.27^{\mathrm{a}}$ & 5.26 & $180^{\mathrm{c}}$ \\
L & 6.56 & 0.97 & $0.28^{\mathrm{a}}$ & 5.27 & $195^{\mathrm{c}}$ \\
M & 6.55 & 0.97 & $0.29^{\mathrm{a}}$ & 5.33 & $374^{\mathrm{b}}$ \\
H & 6.52 & 0.91 & $0.33^{\mathrm{b}}$ & 5.31 & $641^{\mathrm{a}}$ \\
Sign. & ns & ns & $* *$ & Ns & $* *$ \\
\hline
\end{tabular}

The data are presented as means. ${ }^{* *}$ Significance at $p<0.01$; n.s. not significant. Lowercase letters show differences by Tukey's multiple range test.

The results of principal physicochemical and antioxidant analyses of $\mathrm{L}, \mathrm{M}$ and $\mathrm{H}$ of six months brined olives and their brines are reported in Table 4 . The brines did not significantly differ $(p>0.05)$ in $\mathrm{pH}$ (from 4.29 to 4.56 ) and TA (around 0.3\%), in accordance with the values cited in IOC, 2004 [54]. Some differences were instead observed among olives for $\mathrm{pH}$ and aw.

The TPC of olives and brines varied also significantly $(p<0.05)$ : the highest content was quantified

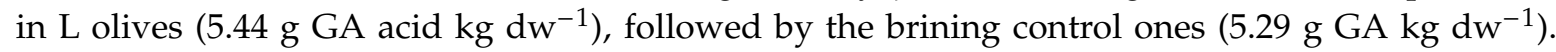
The TPC in brines varied correspondingly from 1.88 to $2.28 \mathrm{~g} \mathrm{GA} \mathrm{L}^{-1}$, due to the diffusion of phenolics from the drupes to the brines during fermentation, as also observed by other authors [58,59]. Similar to the quantified antioxidant content, the antioxidant activity measured by ABTS assay were higher in $\mathrm{L}\left(8.09 \mathrm{mmol}^{\text {Trolox }} \mathrm{g}^{-1}\right)$, followed by $\mathrm{C}, \mathrm{H}$ and $\mathrm{M}$ olives. A lower response to DPPH assay was generally observed, with the highest result in $\mathrm{C}$ samples of $6.43 \mathrm{mmol} \mathrm{Trolox}^{-1}$. The selenium content was drastically reduced by the brining process in all the treated samples, with a final content ranging from $48.60(\mathrm{H})$ to $0.27 \mu \mathrm{g} \mathrm{kg}^{-1}(\mathrm{C})$ and with the following ranking respect to the fresh samples of: $\mathrm{H}>\mathrm{L}>\mathrm{M}>\mathrm{C}$, with a percentage of reduction respectively of 92.4, 93.1, 94.7 and $99.8 \%$ (Figure 3). Surely the derived selenium compounds have a great solubility in the brine solution consequently as an evident diffusion occurred. 
Table 4. Physicochemical and antioxidant characterization of brine and olives after 6 months of fermentation.

\begin{tabular}{|c|c|c|c|c|c|c|}
\hline \multirow[b]{2}{*}{ Brines } & \multirow[b]{2}{*}{ TA (\% Lactic acid) } & \multicolumn{2}{|c|}{ Physicochemical Analysis } & \multicolumn{3}{|c|}{ Antioxidant Capacity } \\
\hline & & $\mathrm{pH}$ & Chlorides (\%) & TPC $\left(\mathrm{g} \mathrm{GA} \mathrm{L}^{-1}\right)$ & ABTS (mmol Trolox $\left.\mathrm{L}^{-1}\right)$ & DPPH $\left(\operatorname{mmol}\right.$ Trolox $\left.\mathrm{L}^{-1}\right)$ \\
\hline BC & 0.28 & 4.29 & 7.80 & $2.28^{\mathrm{a}}$ & $15.65^{\mathrm{b}}$ & $12.25^{\mathrm{b}}$ \\
\hline $\mathrm{L}$ & 0.27 & 4.30 & 7.93 & $2.09 \mathrm{ab}$ & $18.09^{\text {a }}$ & $13.61^{\mathrm{ab}}$ \\
\hline $\mathbf{M}$ & 0.22 & 4.56 & 7.78 & $1.88^{\mathrm{b}}$ & $16.99 \mathrm{ab}$ & $14.81^{\mathrm{a}}$ \\
\hline $\mathbf{H}$ & 0.32 & 4.40 & 7.72 & $1.91^{\mathrm{b}}$ & $15.48^{b}$ & $14.82^{\text {a }}$ \\
\hline Sign. & ns & ns & ns & $* *$ & $* *$ & $*$ \\
\hline Olives & Dry Matter (\%) & $a_{w}$ & $\mathrm{pH}$ & TPC (g GA kg- $\left.\mathrm{dw}^{-1}\right)$ & ABTS (mmol Trolox $\left.\mathrm{g}^{-1}\right)$ & DPPH (mmol Trolox $\left.\mathrm{g}^{-1}\right)$ \\
\hline BC & 32.04 & $0.954^{\mathrm{a}}$ & $5.28^{b}$ & $5.29 \mathrm{ab}$ & $7.77 \mathrm{ab}$ & $6.43^{\mathrm{a}}$ \\
\hline L & 31.48 & $0.947^{\mathrm{b}}$ & $5.80^{\mathrm{a}}$ & $5.44^{\mathrm{a}}$ & $8.09^{a}$ & $5.98^{a b}$ \\
\hline $\mathbf{M}$ & 31.89 & $0.950^{\mathrm{ab}}$ & $5.47^{\mathrm{ab}}$ & $4.14^{\mathrm{c}}$ & $6.66^{\mathrm{b}}$ & $4.85^{\mathrm{c}}$ \\
\hline $\mathbf{H}$ & 31.88 & $0.950^{\mathrm{ab}}$ & $5.43^{\mathrm{ab}}$ & $4.71^{b c}$ & $7.03^{a b}$ & $5.03^{b c}$ \\
\hline Sign. & ns & * & * & $* *$ & $* *$ & $* *$ \\
\hline
\end{tabular}

The data are presented as means. ${ }^{*}$ Significance at $p<0.05 ;{ }^{* *}$ Significance at $p<0.01 ;$ n.s. not significant. Lowercase letters show differences by Tukey's multiple range test. 


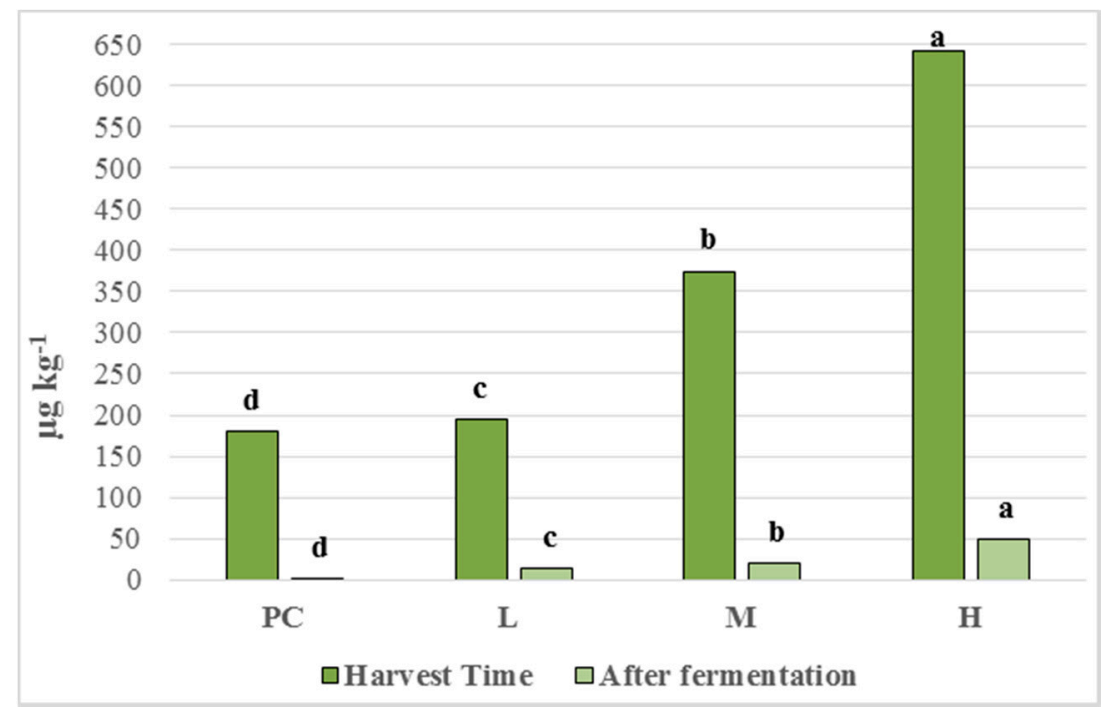

Figure 3. Selenium content in Gordal olive samples at harvest and after fermentation. Lowercase letters show differences by Tukey's multiple range test among the samples for each studied period (at harvest time and after fermentation).

In Table 5 the main characteristics of Carolea olive fruits at harvest are reported. As observed with the first experiment on drupe parameters, no significant $(p>0.05)$ effect among the plant treatments was found on the average weight, which varied from 3.8 to $4.0 \mathrm{~g}$ and ripening index which was close to 7 . The olives obtained by the plants sprayed three and four times (Plant treatments T3 and T4) showed flesh firmness significantly higher than the other samples, although at harvest the fruits were in advanced ripening (with a completely black skin colour and with $100 \%$ purple flesh). No significant difference was recorded with regard to the flesh/stone ratio (with values ranging between 4.5 and 4.7). The results of Selenium content in olives at harvest varied from 16 to $55 \mu \mathrm{g} \mathrm{kg}{ }^{-1}$, in accordance with the number of foliar applications.

Table 5. Physical characteristics of olive fruits cv. "Carolea" at harvest after plant selenate spraying (none, one, two, three and four times respectively for PC, T1, T2, T3, T4).

\begin{tabular}{|c|c|c|c|c|c|}
\hline Treatment & $\begin{array}{l}\text { Fruit Fresh } \\
\text { Weight (g) }\end{array}$ & $\begin{array}{l}\text { Ripening } \\
\text { Index }\end{array}$ & $\begin{array}{l}\text { Flesh Firmness } \\
\text { (kg) }\end{array}$ & Flesh/Stone & $\begin{array}{c}\text { Se Content } \\
\left(\mu \mathrm{g} \mathrm{kg}^{-1}\right)\end{array}$ \\
\hline PC & 3.90 & 6.97 & $0.14^{\mathrm{a}}$ & 4.73 & $16^{\mathrm{d}}$ \\
\hline T1 & 3.84 & 6.97 & $0.17^{\mathrm{a}}$ & 4.52 & $24^{c}$ \\
\hline T2 & 3.88 & 6.97 & $0.18^{\mathrm{a}}$ & 4.49 & $25^{c}$ \\
\hline T3 & 3.85 & 6.96 & $0.25^{b}$ & 4.74 & $33^{b}$ \\
\hline $\mathrm{T} 4$ & 3.99 & 6.94 & $0.30^{\mathrm{c}}$ & 4.66 & $55^{\mathrm{a}}$ \\
\hline Sign. & ns & ns & $* *$ & ns & $* *$ \\
\hline
\end{tabular}

The data are presented as means. ${ }^{* *}$ Significance at $p<0.01$; n.s. not significant; Lowercase letters show differences by Tukey's multiple range test.

Drying processes were conducted until a predetermined dry matter (DM) value of near $90 \%$ (based on weight loss calculation) was reached with different times depending on the applied drying pre-treatments. Their effect in olive samples can be observed in Figure 4: the quantified selenium amounts reflected the applied plant fortifications in terms of number of foliar spraying. Therefore, the most Se-fortified olives were all T4 samples, ranging from 85 to $116 \mu \mathrm{g} \mathrm{kg}^{-1} \mathrm{dw}$. A decrease was generally observed in the dried olives and, among these, the best retention of Se on dry weight was observed on DUT for C, T1, T2 and T4. Dried olives pre-treated in brine (DB) showed instead higher loss \% of Se (25\%-35\%) compared to the corresponding amounts in UT samples for each Se treatment. 


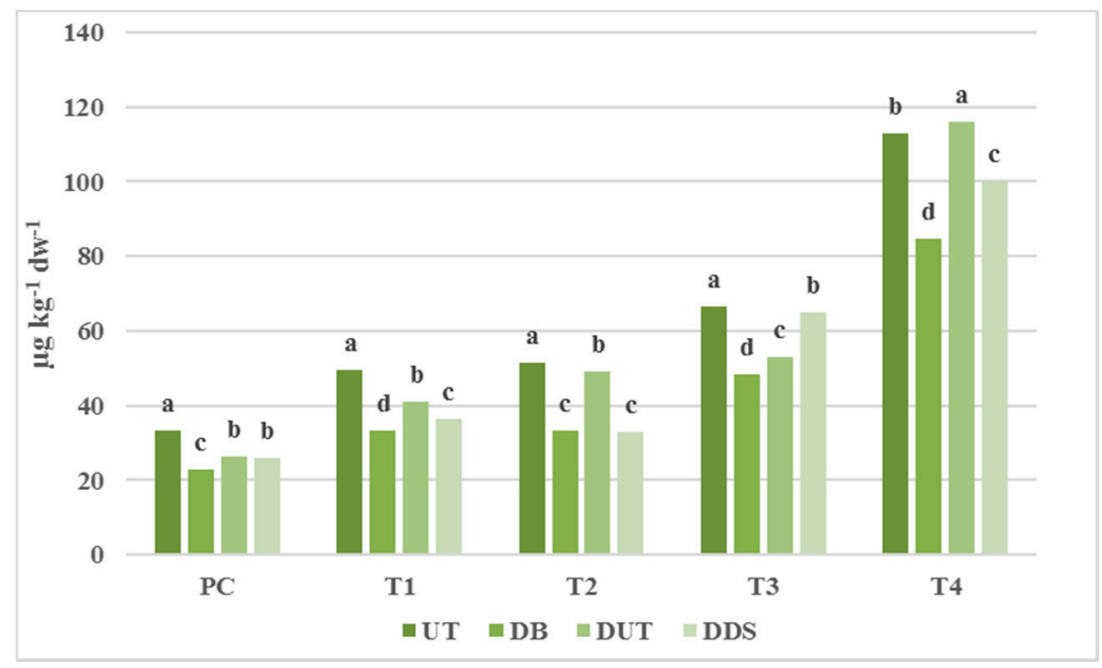

Figure 4. Selenium content of fresh and pre-treated dried olive samples. Lowercase letters show differences by Tukey's post hoc test. PC: Plant Control olives); T1-T4: olives obtained by plant treated with Se once (T1), twice (T2), thrice (T3) and four times (T4); UT: olives not dried; DB: olives treated with brine and then dried; DUT: dried olives without any drying pre-treatment; DDS: olives treated with dry salt and then dried.

In Table 6 results of dry weight, aw, $\mathrm{pH}$, total acidity (TA) and total antioxidant capacity of olive samples are reported. According to the applied drying pre-treatments, different results were observed in olive samples: in particular, \% of dry matter tended to be lower and aw values were higher in T3 olives than in the other samples for each pre-treatment typology. Statistical differences were observed among the samples of the same drying pre-treatment: the samples that showed higher values of TA were those dried without any drying pre-treatment (DUT).

In all T2, T3 and T4 olives, for untreated and pre-treated and dried ones, the total phenolic content was lower than T1 and Plant control ones, so the increasing number of Se-fortification seemed to have opposite effect on the polyphenol amount on drupes.

All the antioxidant determinations (TPC, ABTS and DPPH, Table 6) showed higher values in the fresh samples (UT) before the drying pre-treatments and the thermal processing The TPC values ranged between 9.00 and 73.23 ( $\mathrm{g} \mathrm{GA} \mathrm{kg}^{-1} \mathrm{dw}$ ) respectively in the samples: Brining Control, pre-treated in dried salt (C DDS) and T1 untreated (T1 UT). Also for ABTS assay, the highest value was shown for T1 UT sample (180.31 mmol Trolox kg-1 dw).

The ABTS assay performed in UT olives revealed a constant and/or increased antioxidant activity after Se fortification, whereas the same fortified samples, from T1 UT to T3 UT, showed an increase of DPPH scavenging activity than Plant control ones, similarly to literature [63]. Positive correlation was found between TPC and ABTS assays (C: 0.963; T1: 0.999; T2: 0.999; T3: 0.965; T4: 1.000).

Table 6. Physicochemical and antioxidant characterization of drying treated olives (Exp. 2).

\begin{tabular}{ccccccc}
\hline Analysis & $\begin{array}{c}\text { Plant Treatments/ } \\
\text { Drying Pre-Treatment }\end{array}$ & UT & DUT & DB & DDS & Sign. \\
& PC & $47.95^{\mathrm{B}}$ & $91.20^{\mathrm{aA}}$ & $90.82^{\mathrm{aA}}$ & $92.03^{\mathrm{aA}}$ & $* *$ \\
& T1 & $47.39^{\mathrm{B}}$ & $88.87^{\mathrm{abA}}$ & $88.65^{\mathrm{bA}}$ & $89.23^{\mathrm{bA}}$ & $* *$ \\
& T2 & $47.64^{\mathrm{C}}$ & $85.35^{\mathrm{bcB}}$ & $86.41^{\mathrm{cB}}$ & $89.70^{\mathrm{abA}}$ & $* *$ \\
DM (\%) & T3 & $49.52^{\mathrm{B}}$ & $84.63^{\mathrm{cA}}$ & $86.54^{\mathrm{cA}}$ & $87.82^{\mathrm{bA}}$ & $* *$ \\
& T4 & $48.63^{\mathrm{B}}$ & $88.43^{\mathrm{abcA}}$ & $87.41^{\mathrm{bcA}}$ & $89.96^{\mathrm{abA}}$ & $* *$ \\
& Sign. & ns & $* *$ & $* *$ & $* *$ & \\
\hline
\end{tabular}


Table 6. Cont.

\begin{tabular}{|c|c|c|c|c|c|c|}
\hline Analysis & $\begin{array}{c}\text { Plant Treatments/ } \\
\text { Drying Pre-Treatment }\end{array}$ & UT & DUT & DB & DDS & Sign. \\
\hline \multirow{6}{*}{$a_{w}$} & PC & $0.98^{\mathrm{A}}$ & $0.74^{\mathrm{bB}}$ & $0.66^{\mathrm{cBC}}$ & $0.63^{\mathrm{cC}}$ & $* *$ \\
\hline & $\mathrm{T} 1$ & $0.98^{\mathrm{A}}$ & $0.84^{\mathrm{aB}}$ & $0.82^{\mathrm{aB}}$ & $0.77^{a b C}$ & $* *$ \\
\hline & $\mathrm{T} 2$ & $0.98^{\mathrm{A}}$ & $0.84^{\mathrm{aB}}$ & $0.84^{\mathrm{aB}}$ & $0.78^{\mathrm{aC}}$ & $* *$ \\
\hline & T3 & $0.97^{\mathrm{A}}$ & $0.84^{\mathrm{aB}}$ & $0.81^{\mathrm{aC}}$ & $0.79 \mathrm{aC}$ & $* *$ \\
\hline & $\mathrm{T} 4$ & $0.98^{\mathrm{A}}$ & $0.79 \mathrm{abB}$ & $0.73^{b C}$ & $0.72^{b C}$ & $* *$ \\
\hline & Sign. & ns & $* *$ & $* *$ & $* *$ & \\
\hline \multirow{6}{*}{$\mathrm{pH}$} & PC & $5.60 \mathrm{a}^{\mathrm{A}}$ & $5.40 \mathrm{a}^{\mathrm{B}}$ & $5.49 \mathrm{AB}$ & $5.46 \mathrm{a}^{\mathrm{AB}}$ & * \\
\hline & $\mathrm{T} 1$ & $5.47^{\mathrm{bA}}$ & $5.07 \mathrm{bB}$ & $5.58^{\mathrm{A}}$ & $5.30 \mathrm{bAB}$ & $* *$ \\
\hline & $\mathrm{T} 2$ & $5.51^{\mathrm{abA}}$ & $5.24^{\mathrm{abC}}$ & $5.57^{\mathrm{A}}$ & $5.41^{\mathrm{abB}}$ & $* *$ \\
\hline & T3 & $5.51 \mathrm{abA}$ & $5.32^{\mathrm{abB}}$ & $5.59^{\mathrm{A}}$ & $5.33^{\mathrm{abB}}$ & $* *$ \\
\hline & $\mathrm{T} 4$ & $5.56^{\mathrm{abA}}$ & $5.29^{a b C}$ & $5.53 \mathrm{AB}$ & $5.45^{\mathrm{aB}}$ & $* *$ \\
\hline & Sign. & * & * & ns & $* *$ & \\
\hline \multirow{6}{*}{ TA (\%) } & PC & $0.62^{\mathrm{A}}$ & $0.99^{\mathrm{B}}$ & $0.87^{\mathrm{bBC}}$ & $0.74^{\mathrm{C}}$ & ** \\
\hline & $\mathrm{T} 1$ & $0.59^{\mathrm{A}}$ & $1.09^{\mathrm{A}}$ & $0.87^{\mathrm{bB}}$ & $0.78^{\mathrm{B}}$ & $* *$ \\
\hline & $\mathrm{T} 2$ & $0.56^{\mathrm{A}}$ & $1.01^{\mathrm{A}}$ & $0.85^{\mathrm{bB}}$ & $0.66^{\mathrm{C}}$ & $* *$ \\
\hline & T3 & $0.57^{\mathrm{A}}$ & $1.01^{\mathrm{A}}$ & $0.73^{\mathrm{bB}}$ & $0.74^{\mathrm{B}}$ & $* *$ \\
\hline & $\mathrm{T} 4$ & $0.62^{\mathrm{A}}$ & $1.03^{\mathrm{A}}$ & $1.07^{\mathrm{aA}}$ & $0.63^{\mathrm{B}}$ & $* *$ \\
\hline & Sign. & ns & ns & $* *$ & ns & \\
\hline \multirow{6}{*}{$\begin{array}{c}\text { TPC } \\
\left(\mathrm{g} \mathrm{GA} \mathrm{kg}^{-1} \mathrm{dw}\right)\end{array}$} & PC & $67,61^{\mathrm{aA}}$ & $21,77^{\mathrm{aB}}$ & $9,10^{\mathrm{dB}}$ & $9,00^{d B}$ & $* *$ \\
\hline & $\mathrm{T} 1$ & $73,23^{\mathrm{aA}}$ & 23,49 aBC & $27,19^{\mathrm{aB}}$ & $22,21^{\mathrm{aC}}$ & $* *$ \\
\hline & $\mathrm{T} 2$ & $59,53^{b A}$ & $18,65^{\mathrm{bB}}$ & $14,11^{\mathrm{cC}}$ & $13,13^{\mathrm{cC}}$ & $* *$ \\
\hline & $\mathrm{T} 3$ & $30,60 \mathrm{dA}$ & $12,76^{\mathrm{dB}}$ & 15,56 bB & 15,77 bB & $* *$ \\
\hline & $\mathrm{T} 4$ & $44,61^{\mathrm{cA}}$ & $15,77 \mathrm{cB}$ & $15,35 \mathrm{bcB}$ & $13,80^{\mathrm{cB}}$ & $* *$ \\
\hline & Sign. & $* *$ & $* *$ & $* *$ & $* *$ & \\
\hline \multirow{6}{*}{$\begin{array}{c}\text { ABTS } \\
\left(\mathrm{mmol} \text { Trolox } \mathrm{kg}^{-1} \mathrm{dw}\right)\end{array}$} & PC & $145,12^{\mathrm{bA}}$ & $71,45^{\mathrm{aB}}$ & $65,32 \mathrm{bB}$ & $73,29 \mathrm{~dB}$ & $* *$ \\
\hline & $\mathrm{T} 1$ & $180,31^{\mathrm{aA}}$ & $57,41 \mathrm{bcB}$ & $66,85^{\mathrm{bB}}$ & 66,47 eB & $* *$ \\
\hline & $\mathrm{T} 2$ & $146,85^{\mathrm{bA}}$ & $53,01^{\mathrm{cC}}$ & $58,42^{\mathrm{cC}}$ & $90,58^{\mathrm{bB}}$ & $* *$ \\
\hline & $\mathrm{T} 3$ & $153,08^{\mathrm{bA}}$ & $60,58^{\mathrm{bC}}$ & $58,13^{\mathrm{cC}}$ & $84,35^{\mathrm{cB}}$ & $* *$ \\
\hline & $\mathrm{T} 4$ & $142,60^{\mathrm{bA}}$ & $70,24{ }^{\mathrm{aC}}$ & $69,99 \mathrm{aC}$ & $103,48^{a B}$ & $* *$ \\
\hline & Sign. & $* *$ & $* *$ & $* *$ & $* *$ & \\
\hline \multirow{6}{*}{$\begin{array}{c}\text { DPPH } \\
\left(\text { IC50 } \mu \mathrm{g} \mathrm{g}^{-1} \mathrm{dw}\right)\end{array}$} & PC & 194,29 cA & $35,89 \mathrm{cB}$ & $49,18^{\mathrm{bB}}$ & $38,26^{\mathrm{B}}$ & ** \\
\hline & $\mathrm{T} 1$ & $237,29 \mathrm{bA}$ & $33,49 \mathrm{cD}$ & $48,04^{\mathrm{bB}}$ & $38,18^{\mathrm{C}}$ & $* *$ \\
\hline & $\mathrm{T} 2$ & $243,86^{a b A}$ & 57,33 bB & $46,76^{\mathrm{bC}}$ & $43,69^{C}$ & $* *$ \\
\hline & $\mathrm{T} 3$ & $272,21^{\mathrm{aA}}$ & $71,02^{\mathrm{aB}}$ & $59,36^{\mathrm{aBC}}$ & $44,15^{C}$ & $* *$ \\
\hline & $\mathrm{T} 4$ & $200,24^{c A}$ & 56,89 bB & $49,77^{b B}$ & $42,17^{\text {B }}$ & $* *$ \\
\hline & Sign. & $* *$ & $* *$ & $* *$ & ns & \\
\hline
\end{tabular}

The data are presented as means * Significance at $p<0.05 ; * *$ Significance at $p<0.01 ;$ n.s. not significant; Letters show differences by Tukey's multiple range test (lowercase for differences in the column and uppercase in the row).

In Table 7 the results of multivariate analysis for all the samples (exp.2) are reported. All the variables and their combination affected significantly the studied parameters.

Table 7. Multivariate statistical analysis of treated samples.

\begin{tabular}{cccc}
\hline Analysis & $\begin{array}{c}\text { Se Spraying Number } \\
\text { (S) }\end{array}$ & $\begin{array}{c}\text { Drying Pre-Treatment } \\
\text { (DP) }\end{array}$ & S $\times$ DP \\
\hline DM & $* *$ & $* *$ & $* *$ \\
$\mathbf{a}_{\mathbf{W}}$ & $* *$ & $* *$ & $* *$ \\
pH & $* *$ & $* *$ & $* *$ \\
TA & $* *$ & $* *$ & $*$ \\
TPC & $* *$ & $* *$ & $* *$ \\
ABTS & $* *$ & $* *$ & $* *$ \\
DPPH & $* *$ & $* *$ & \\
\hline
\end{tabular}

** Significance at $p<0.01$ 


\section{Discussion}

Foliar application of Se solution has been applied to increase the Se content in many agricultural products [73]. In this work, we studied the accumulation of Se in olives in two different olive cultivars, observing the variation of the different concentrations after the agronomic and technological treatments. The increase in the flesh firmness of the olives following the foliar applications of selenium during fruit growth was confirmed by results of previous experiments conducted on peach [42]. Several studies have evidenced that selenium treatments are able to delay fruit ripening and prolong the shelf-life of fruits and vegetables $[36,38,46]$. Particularly, a recent study conducted on tomato showed that selenium treatments are able to negatively interfere with the biosynthesis of ethylene [1-aminocyclopropane-1-carboxylic acid (ACC) synthase and ACC oxidase] [74], with a consequent decrease in this hormone and in the fruit respiration rate. Probably, the selenium treatment also manages to enhance the antioxidant defense system by reducing ROS generation and membrane damage. This has been attributed to the higher glutathione content and the increased activity of the enzymes glutathione peroxidase and glutathione reductase and decreased lipid peroxidation [75-78]. The different selenium content in the olives of Gordal and Carolea cultivars could be attributed to the different structure of the epidermal cells, and the epicuticular waxes deposited on the surface of the leaves and fruits of the two varieties. In fact, these structural characteristics significantly influenced the rate of uptake of foliar nutrient sprays [79]. The methods to eliminate the bitter compound (oleuropein) from olives cause an increase in the permeability of the cell membrane, promoting the lack of some components from pulp to brine: the fermentation process (which lasted six months) involved a loss of selenate from olives to brines in our first experiment.

Olive polyphenols represent a class of relevant antioxidant compounds that play an important role in human nutrition for the prevention of several diseases [80]. Particularly in the last years the aim of the research on table olives has been addressed on the revalorization from a nutritional and functional point of view, mainly for the properties of phenolic compounds (with high biological value) [81]. The Se application have an influence on the firmness of flesh, as previous reported. The olive TPC could be partially linked to the derived from the selenium treatment firmness of flesh: it may not allow phenol diffusion toward brine solution. The trend is not strictly related to treatment, in fact the lowest TPC value was showed by the $M$ treatment.

The best treatment for olives was the drying for the Se retention in olive pulp. A general decrease of total acidity in olive samples was observed after drying, as confirmed by literature for dried fruits submitted to hot air drying $[82,83]$. Opposite effect of selenium fortification on phenolic compounds and antioxidant activities in vegetables and fruits was reported in literature: no effect [84] and a positive one [85]. After Se fortification a constant and/or an increased antioxidant activity (ABTS and DPPH) was revealed in tested olive productions. These results can be correlated to a synthesis of other antioxidant constituents after Se-fortification, as glutathione, with recognized antioxidant properties [74]. Fruit dehydration involves a lack of several nutrients, among other also polyphenols, as confirmed by literature [86,87]. In our study the tested drying pre-treatments seemed promote the bioactive compounds depletion, probably for a faster dissolution of water-soluble components, that was observed in particular in olives from no treated plants. Also the amount of selenium seemed to be affected more by the pre-treatment in brine than in dry salt.

\section{Conclusions}

In this work the obtainment of Se fortified olives was achieved by plant treatments (foliar spraying at different selenate concentrations) with the best result of $650 \mu \mathrm{g} \mathrm{kg}^{-1}$ of pulp. Olives must be processed to be edible, so brining and drying treatments were evaluated. The first did not produce good Se retention results because this element diffused from pulp to brine and was not largely available for human intake. The drying process maintained better Se content in olives, but the drying pre-treatment greatly influenced the final content of selenium-derived compounds. The best results were obtained in 
untreated before drying and treated with dry salt ones, that could contribute to the daily Se intake assumed individually or as ingredient in more elaborate dishes.

Author Contributions: All authors have read and agree to the published version of the manuscript. R.M. and M.P. conceived and designed the experiments; A.D.B., R.M. and F.C. performed the experiments; A.D.B., A.P. and R.M. analysed the data; A.P., R.M. and M.P. edited and revised the paper; A.D.B. and R.M. wrote the paper.

Funding: This research received no external funding.

Conflicts of Interest: The authors declare no conflict of interest.

\section{References}

1. Rouached, H. Recent developments in plant zinch omeostasis and the path toward improbe biofortification and phytoremediation programs. Plant. Signal. Behav. 2013, 8, e22681. [CrossRef] [PubMed]

2. Puccinelli, M.; Malorgio, F.; Pezzarossa, B. Selenium Enrichment of Horticultural Crops. Molecules 2017, 22, 933. [CrossRef] [PubMed]

3. Haug, A.; Graham, R.; Christophersen, O.; Lyons, G. How to use the world's scarce selenium resources efficiently to increase the selenium concentration in food. Microb. Ecol. Health Dis. 2007, 19, 209-228.

4. Banuelos, G.S.; Lin, Z.Q. Use and Development of Biofortified Agricultural Products; CRC Press: Boca Raton, FL, USA, 2009; pp. 17-70.

5. Zhu, Y.G.; Pilon-Smits, E.A.H.; Zhao, F.J.; Williams, P.N.; Meharg, A.A. Selenium in higher plants: Understanding mechanisms for biofortification and phytoremediation. Trends Plant. Sci. 2009, 14, 436-442. [CrossRef]

6. Bouis, H.E.; Welch, R.M. Biofortification-a sustainable agricultural strategy for reducing micronutrient work in the Global South. Crop. Sci. 2010, 50, S20-S32. [CrossRef]

7. Lyons, G.; Cakmak, I. Agronomic biofortification of food crops with micronutrients. In Fertilizing Crops to Improve Human Health: A Scientific Review; Bruulsema, T.W., Heffer, P., Welch, R.M., Cakmak, I., Moran, K., Eds.; International Plant Nutrition Institute: Norcross, GA, USA, 2012; pp. 97-122.

8. Combs, G.F. Food system-based approaches to improving micronutrient nutrition: The case for selenium. Biofactors 2000, 12, 39-43. [CrossRef] [PubMed]

9. White, P.J.; Brown, P.H. Plant nutrition for sustainable development and global health. Ann. Bot. 2010, 105, 1073-1080. [CrossRef]

10. Fairweather-Tait, S.J.; Bao, Y.; Broadley, M.R.; Collings, R.; Ford, D.; Hesketh, J.E.; Hurst, R. Selenium in human health and disease. Antioxid. Redox Sign. 2011, 14, 1337-1383. [CrossRef]

11. Méplan, C.; Hesketh, J. The influence of selenium and selenoprotein gene variants on colorectal cancer risk. Mutagenesis 2012, 27, 177-186. [CrossRef]

12. Rayman, M.P. Selenium and human health. Lancet 2012, 379, 1256-1268. [CrossRef]

13. Fordyce, F.M. Selenium deficiency and toxicity in the environment. In Essentials of Medical Geology, Revised Edition; Selinus, O., Ed.; Springer: Dordrecht, The Netherlands, 2005; pp. 375-415.

14. Krinsky, N.; Beecher, G.R.; Burk, R.F.; Chan, A.C.; Erdman, J.W.; Jacob, R.A.; Jialal, I.; Kolonel, L.N.; Marshall, J.R.; Taylor Mayne, P.R.L.; et al. Dietary Reference Intakes for Vitamin C, Vitamin E, Selenium, and Carotenoids; Institute of Medicine; The National Academies Press: Washington, DC, USA, 2000.

15. Rosenfeld, I.; Beath, O.A. Selenium. Geobotany, Biochemistry, Toxicity and Nutrition; Academic Press: New York, NY, USA, 1964; p. 411.

16. Terry, N.; Zayed, A.M.; de Souza, M.P.; Tarun, A.S. Selenium in higher plants. Annu. Rev. Plant. Physiol. Plant Mol. Biol. 2000, 51, 401-432. [CrossRef]

17. Dhillon, K.S.; Dhillon, S.K. Distribution and management of seleniferous soils. Adv. Agro. 2003, 79, 119-185.

18. White, P.J.; Bowen, H.C.; Parmaguru, P.; Fritz, M.; Spracklen, P.; Spiby, E.; Meacham, C.; Mead, A.; Harriman, M.; Trueman, L.J.; et al. Interactions between selenium and sulphur nutrition in Arabidopsis thaliana. J. Exp. Bot. 2004, 55, 1927-1937. [CrossRef] [PubMed]

19. Rani, N.; Dhillon, K.S.; Dhillon, S.K. Critical levels of selenium in different crops grown in an alkaline silty loam soil treated with selenite-Se. Plant Soil 2005, 277, 367-374. [CrossRef]

20. Gupta, M.; Gupta, S. An overview of selenium uptake, metabolism, and toxicity in plants. Front. Plant Sci. 2017. [CrossRef] 
21. White, P.J.; Broadley, M.R. Biofortification of crops with seven mineral elements often lacking in human diets-iron, zinc, copper, calcium, magnesium, selenium, and iodine. New Phytol. 2009, 182, 49-84. [CrossRef]

22. Bodnar, M.; Konieczka, P.; Namiesnik, J. The properties, functions, and use of selenium compounds in living organisms. J. Environ. Sci. Health Part C 2012, 30, 225-252. [CrossRef]

23. Wu, Z.; Bañuelos, G.S.; Lin, Z.Q.; Liu, Y.; Yuan, L.; Yin, X.; Li, M. Biofortification and phytoremediation of selenium in China. Front. Plant Sci. 2015, 6, 136. [CrossRef]

24. Sors, T.G.; Ellis, D.R.; Na, G.N.; Lahner, B.; Lee, S.; Leustek, T.; Pickering, I.J.; Salt, D. Analysis of sulfur and selenium assimilation in Astragalus plants with varying capacities to accumulate selenium. Plant $J$. 2005, 42, 785-797. [CrossRef]

25. Missana, T.; Alonso, U.; García-Gutiérrez, M. Experimental study and modeling of selenite sorption onto illite and smectite clays. J. Colloid Interface Sci. 2009, 334, 132-138. [CrossRef]

26. Li, H.F.; McGrath, S.P.; Zhao, F.J. Selenium uptake, translocation and speciation in wheat supplied with selenate or selenite. New Phytol. 2008, 178, 92-102. [CrossRef] [PubMed]

27. Feist, L.J.; Parker, D.R. Ecotypic variation in selenium accumulation among populations of Stanleya pinnata. New Phytol. 2001, 149, 61-69. [CrossRef]

28. Zhang, Y.; Pan, G.; Chen, J.; Hu, Q. Uptake and transport of selenite and selenate by soybean seedlings of two genotypes. Plant Soil 2003, 253, 437-443. [CrossRef]

29. Malagoli, M.; Schiavon, M.; dall'Acqua, S.; Pilon-Smits, E.A. Effects of selenium biofortification on crop nutritional quality. Front. Plant. Sci. 2015, 6, 280. [CrossRef]

30. Ximénez-Embún, P.; Alonso, I.; Madrid-Albarrán, Y.; Cámara, C. Establishment of selenium uptake and species distribution in lupine, Indian mustard, and sunflower plants. J. Agric. Food Chem. 2004, 52, 832-838. [CrossRef]

31. White, P.J.; Broadley, M.R.; Bowen, H.C.; Johnson, S.E. Selenium and its relationship with sulfur. In Sulfur in Plants-An Ecological Perspective; Hawkesford, M.J., de Kok, L.J., Eds.; Springer: Dordrecht, The Netherlands, 2007; pp. 225-252.

32. Pilon-Smits, E.A.H. Plant selenium metabolism-genetic manipulation, phytotechnological applications, and ecological implications. In Environmental Contamination: Health Risks and Ecological Restoration; Wong, M.H., Ed.; CRC Press: Boca Raton, FL, USA, 2012; pp. 293-311.

33. Pilon-Smits, E.A.H.; LeDuc, D.L. Phytoremediation of selenium using transgenic plants. Curr. Opin. Biotech. 2009, 20, 207-212. [CrossRef]

34. Bisberg, B.; Gissel-Nielsen, G. The uptake of applied selenium by agricultural plants. 1. The influence of soil type and plant species. Plant Soil 1969, 31, 287-298. [CrossRef]

35. Gissel-Nielsen, G.; Bisberg, B. The uptake of applied selenium by agricultural plants. 2. The utilization of various selenium compounds. Plant Soil 1970, 32, 382-396. [CrossRef]

36. Pezzarossa, B.; Malorgio, F.; Tonutti, P. Effects of selenium uptake by tomato plants on senescence, fruit ripening and ethylene evolution. In Biology and Biotechnology of the Plant Hormone Ethylene II; Chang, A.K., Klee, C., Bleecker, H., Pech, A.B., Grierson, D.J.C., Eds.; Academic Publishers: Dordrecht, The Netherlands, 1999; pp. 275-276.

37. Tsuneyoshi, T.; Yoshida, J.; Takashi, S. Hydroponic cultivation offers. A practical means of producing selenium-enriched garlic. J. Nutr. 2006, 136, 870S-872S. [CrossRef]

38. Malorgio, F.; Diaz, K.; Ferrante, A.; Mensuali, A.; Pezzarossa, B. Effects of selenium addition on minimally processed leafy vegetables grown in floating system. J. Agric. Food Chem. 2009, 89, 2243-2251. [CrossRef]

39. Ferrarese, M.; Mahmoodi Sourestani, M.; Quattrini, E.; Schiavi, M.; Ferrante, A. Biofortification of spinach plants applying selenium in the nutrient solution of floating system. Veg. Crops Res. Bull. 2012, 76, 127-136. [CrossRef]

40. D'Amato, R.; Proietti, P.; Nasini, L.; Del Buono, D.; Tedeschini, E.; Businelli, D. Increase in the selenium content of extra virgin olive oil: Quantitative and qualitative implications. Grasas Aceites 2014, 65, e025.

41. Kopsell, D.A.; Sams, C.E.; Barickman, T.C.; Deyton, D.E. Selenization of basil and cilantro through foliar applications of selenate-selenium and selenite-selenium. Hortscience 2009, 44, 438-442. [CrossRef]

42. Pezzarossa, B.; Remorini, D.; Gentile, M.L.; Massai, R. Effects of foliar and fruit addition of sodium selenate on selenium accumulation and fruit quality. J. Sci. Food Agric. 2012, 92, 781-786. [CrossRef] [PubMed]

43. Gupta, U.C.; Winter, K.A.; McRae, K.B. Selenium application of crops through foliar applications. Can. J. Soil Sci. 1988, 68, 519-526. [CrossRef] 
44. Winkel, L.; Vriens, B.; Jones, G.; Schneider, L.; Pilon-Smits, E.; Banuelos, G. Selenium cycling across soil-plant-atmosphere interfaces: A critical review. Nutrients 2015, 7, 4199-4239. [CrossRef]

45. Ros, G.; van Rotterdam, A.; Bussink, D.; Bindraban, P. Selenium fertilization strategies for bio-fortification of food: An agro-ecosystem approach. Plant Soil 2016, 404, 99-112. [CrossRef]

46. Guo, Y.; Wang, Y.N.; Han, T. Changes of physiology and fruit quality in stored nectarine treated with selenium and boron. J. Beijing Agric. College 2005, 20, 1-4.

47. Liu, Q.; Ning, C.; Wang, D.; Wenjiang, W.; Guoliang, W. Effect of spraying selenium on the pear fruit quality. Acta Hort. 2012, 940, 545-549.

48. Babalar, M.; Mohebbi, S.; Zamani, Z.; Askari, M.A. Effect of foliar application with sodium selenate on selenium biofortification and fruit quality maintenance of 'Starking Delicious' apple during storage. J. Sci. Food Agric. 2019, 99, 5149-5156. [CrossRef]

49. Groth, S.; Budke, C.; Neugart, S.; Ackermann, S.; Kappenstein, F.S.; Daum, D.; Rohn, S. Influence of a Selenium Biofortification on Antioxidant Properties and Phenolic Compounds of Apples (Malus domestica). Antioxidants 2020, 9, 187. [CrossRef] [PubMed]

50. Proietti, P.; Nasini, L.; Del Buono, D.; D'Amato, R.; Tedeschini, E.; Businelli, D. Selenium protects olive (Olea europaea L.) from drought stress. Sci. Hortic. 2013, 164, 165-171. [CrossRef]

51. D'Amato, R.; De Feudis, M.; Hasuoka, P.E.; Regni, L.; Pacheco, P.H.; Onofri, A.; Businelli, D.; Proietti, P. The Selenium Supplementation Influences Olive Tree Production and Oil Stability Against Oxidation and Can Alleviate the Water Deficiency Effects. Frontiers Plant Sci. 2018, 9, 1191. [CrossRef] [PubMed]

52. D’Amato, R.; Proietti, P.; Onofri, A.; Regni, L.; Esposto, S.; Servili, M.; Businelli, D.; Selvaggini, R. Biofortification (Se): Does it increase the content of phenolic compounds in virgin olive oil (VOO)? PLoS ONE 2017, 12, e0176580.

53. IOC. Table Olive Consumption. Available online: http://www.internationaloliveoil.org/documents/viewfile/ 4195-consommation3-ang/ (accessed on 14 May 2017).

54. Young, V.R. Adult amino acid requirements: The case for a major revision in current recommendations. J. Nutr. 1994, 124, 1517S-1523S. [CrossRef]

55. Imura, K.; Okada, A. Amino acid metabolism in pediatric patients. Nutrition 1998, 14, 143-148. [CrossRef]

56. Delplanque, B. Intérêt nutritionnel des huiles d'olives. OCL-Ol. Corps Gras Li. 1998, 6, 1-6.

57. Irmak, S. Table Olives \& Our Health \& Quality. J. Nutr. Diet. Pract. 2018, 2, 001-004.

58. Ray, N.; Lam, N.; Luc, R.; Bonvino, N.; Karagiannis, T. Cellular and molecular effects of bioactive phenolic compounds in olives and olive oil. In Olive and Olive Oil Bioactive Constituents; Boskou, D., Ed.; AOCS Press: Urbana, IL, USA, 2015; pp. 53-91.

59. Silva, S.; Sepodes, B.; Rocha, J.; Direito, R.; Fernandes, A.; Brites, D.; Figueira, M.E. Protective effects of hydroxytyrosol-supplemented refined olive oil in animal models of acute inflammation and rheumatoid arthritis. J. Nutr. Biochem. 2015, 26, 360-368. [CrossRef]

60. Jimenez, A.; Rodriguez, R.; Fernandez-Caro, I.; Guillen, R.; Fernandez-Bolanos, J.; Heredia, A. Dietary fibre content of table olives processed under different European styles: Study of physico-chemical characteristics. J. Sci. Food Agric. 2000, 80, 1903-1908. [CrossRef]

61. López-López, A.; Jiménez-Araujo, A.; García-García, P.; Garrido-Fernández, A. Multivariate analysis for the evaluation of fiber, sugars, and organic acids in commercial presentations of table olives. J. Agric. Food Chem. 2007, 55, 10803-10811. [CrossRef] [PubMed]

62. Dugo, G.; La Pera, L.; Giuffrida, D.; Salvo, F.; Lo Turco, V. Influence of the olive variety and the zone of provenience on selenium content determined by cathodic stripping potentiometry (CSP) in virgin olive oils. Food Chem. 2004, 88, 135-140.

63. Garrido Fernández, A.; Fernández-Díez, M.J.; Adams, R.M. Production and processing. In Table olives; Springer: London, UK, 1997.

64. Sánchez Gómez, A.H.; Garciá Garciá, P.; Rejano Navarro, L. Elaboration of table olives. Grasas Aceites 2006, 57, 86-94. [CrossRef]

65. Mettouchi, S.; Bey, M.B.; Tamendjari, A.; Louaileche, H. Antioxidant activity of table olives as influenced by processing method. Int. J. Chem. Biomol. 2016, 2, 8-14.

66. Romeo, F.V.; Piscopo, A.; Poiana, M. Effect of drying, chemical and natural processing methods on black Biancolilla olives. Grasas Aceites 2012, 63, 223-230. [CrossRef] 
67. Ünal, K.; Nergiz, C. The effect of table olive preparing methods and storage on the composition and nutritive value of table olives. Grasas Aceites 2003, 54,71-76. [CrossRef]

68. Uceda, M.; Frias, L. Harvest Dates. Evolution of the Fruit Oil Content, Oil Composition and Oil Quality. In Proceedings of the II Seminario Oleícola Internacional; International Olive Oil Council: Cordoba, Spain, 1975; pp. 125-130.

69. Fernández-Diez, M.J.; Castro, R.; Fernández, A.; Cancho, F.G.; Pellissó, F.G.; Vega, M.N.; Moreno, A.H.; Mosquera, I.M.; Navarro, L.R.; Quintana, M.C.D.; et al. Biotecnología de la Aceituna de Mesa; Instituto de la Grasa y sus Derivados: Sevilla, Spain, 1985.

70. Othman, B.N.; Roblain, D.; Thonart, P.; Hamdi, M. Tunisian table olive phenolic compounds and their antioxidant capacity. J. Food Sci. 2008, 73, C235-C240. [CrossRef]

71. Brand-Williams, W.; Cuvelier, M.E.; Berset, C. Use of free radical method to evaluate antioxidant activity. Lebensm Wiss. Technol. 1995, 28, 25-30. [CrossRef]

72. De Bruno, A.; Zappia, A.; Piscopo, A.; Poiana, M. Qualitative evaluation of fermented olives grown in Southern Italy (cvs. Carolea, Grossa of Gerace and Nocellara Messinese). Emir J. Food Agr. 2019, 31, 587-596. [CrossRef]

73. Fontanella, M.C.; D'Amato, R.; Regni, L.; Proietti, P.; Beone, G.M.; Businelli, D. Selenium speciation profiles in biofortified sangiovese wine. J. Trace Elem. Med. Bio. 2017, 43, 87-92. [CrossRef]

74. Zhu, Z.; Chen, Y.; Shi, G.; Zhang, X. Selenium delays tomato fruit ripening by inhibiting ethylene biosynthesis and enhancing the antioxidant defense system. Food Chem. 2017, 219, 179-184. [CrossRef] [PubMed]

75. Hartikainen, H.; Xue, T.L.; Piironen, V. Selenium as an anti-oxidant and pro-oxidant in ryegrass. Plant Soil 2000, 225, 193-200. [CrossRef]

76. Cartes, P.; Gianfera, L.; Mora, M.L. Uptake of selenium and its antioxidative activity in ryegrass when applied a selenate and selenite forms. Plant Soil 2005, 276, 359-367. [CrossRef]

77. Djanaguiraman, M.; Devi, D.D.; Shanker, A.K.; Sheeba, A.; Bangarusamy, U. Selenium-an antioxidative protectant in soybean during senescence. Plant Soil 2005, 272, 77-86. [CrossRef]

78. Hasanuzzaman, M.; Hossain, M.A.; Fujita, M. Selenium in higher plants: Physiological role, antioxidant metabolism and abiotic stress tolerance. J. Plant Sci. 2010, 5, 354-375.

79. Fernández, V.; Sotiropoulos, T.; Brown, P.H. Foliar Fertilisation: Principles and Practices, 1st ed.; International Fertilizer Industry Association (IFA): Paris, France, 2013.

80. Piscopo, A.; De Bruno, A.; Zappia, A.; Poiana, M. Antioxidant activity of dried green olives (Carolea cv.). LWT Food Sci Technol. 2014, 58, 49-54. [CrossRef]

81. Boskou, D. Table Olives: A Vehicle for the Delivery of Bioactive Compounds. J. Exp. Food Chem. 2017, 3, 1000123. [CrossRef]

82. Piscopo, A.; Romeo, F.V.; Poiana, M. Effect of drying process on almond (Prunus dulcis (Mill.) D.A. Webb) Kernel composition. Riv. Ital. Sostanze Gr. 2011, 88, 153-160.

83. Piga, A.; Poiana, M.; Pinna, I.; Agabbio, M.; Mincione, A. Drying performance of five Italian apricot cultivars. Sci. Aliment. 2004, 24, 247-259. [CrossRef]

84. Mezeyová, I.; Hegedusova, A.; Andrejiová, A.; Hegedus, O.; Golian, M. Phytomass and content of essential oils in Ocimum basilicum after foliar treatment with selenium. J. Int. Sci. Publ. 2016, 4, 19-27.

85. Schiavon, M.; Dall'Acqua, S.; Mietto, A.; Pilon-Smits, E.A.H.; Sambo, P.; Masi, A.; Malagoli, M. Selenium fertilization alters the chemical composition and antioxidant constituents of tomato (Solanum lycopersicon L.). J. Agric. Food Chem. 2013, 61, 10542-10554. [CrossRef] [PubMed]

86. Madrau, M.A.; Piscopo, A.; Sanguinetti, A.M.; Del Caro, A.; Poiana, M.; Romeo, F.V.; Piga, A. Effect of drying temperature on polyphenolic content and antioxidant activity of apricots. Eur. Food Res. Technol. 2009, 228, 441-448. [CrossRef]

87. Piscopo, A.; De Bruno, A.; Zappia, A.; Poiana, M. Increase in antioxidant activity of brined olives (Carolea cv.) thermally treated in different packaging types. Eur. J. Lipid Sci. Technol. 2016, 118, 1132-1140.

(C) 2020 by the authors. Licensee MDPI, Basel, Switzerland. This article is an open access article distributed under the terms and conditions of the Creative Commons Attribution (CC BY) license (http://creativecommons.org/licenses/by/4.0/). 